\title{
THE IMPACT OF AUDITED FINANCIAL STATEMENTS ON CREDIT RISK ASSESSMENT IN THE BANKING SYSTEM OF KOSOVO (PERIOD 2014-2018)
}

\author{
Albina KALIMASHI ${ }^{1}$, Yllka AHMETI ${ }^{2}$, Ardi AHMETI ${ }^{3}$ \\ ${ }^{1,3}$ University of Prishtina, Faculty of Economics, Prishtina 10000, Kosova \\ ${ }^{2}$ University of Tetovo, Faculty of Economics, Tetovo 1220, North Macedonia
}

Corresponding author's e-mail: ahmeti.yllka@gmail.com

\begin{abstract}
The main goal of the present research is to address the role and importance of audited financial statements in increasing the efficiency of credit risk management in the banking system of Kosovo. In addition, the research will help users understand the financial statement assurance process and the audit process work for a proper assessment of credit risk by banks. The research is treated in sections as below: the first section includes a review of literature (theoretical and empirical review) related to theoretical concepts regarding the importance and development of financial statement audit at financial institutions, in region and beyond. The second section includes a general overview of the relationship between audit of financial statements of clients that establish financial relations with banks and credit risk management. The third section presents the results of the survey and the confirmation of the formulated hypotheses. The last part of the paper presents conclusions and recommendations that have arisen from our study. The main method during our research has been the use of qualitative/quantitative analysis, which has been carried out during various techniques, among which the main ones are the survey interviews \& internal observation of processes based on our own professional experience in the banking channels. The paper aspires to provide a better understanding of challenges in assuring qualitative accounting information for decision-making, as well as presents the basis for further study of this issue in the future. The results of the study aim at adding the value to regulatory bodies' documents such as politics/strategies/instructions and also setting new rules in regard to credit risk management.
\end{abstract}

Keywords: BoD - Board of Directors, CBK-Central Bank of Kosovo, CRMCredit Risk Management, SM - Senior Management, NPL - Non-performing loans, Auditing, Financial Statements.

\section{INTRODUCTION}

The last financial crisis showed us that credit risk was an important source of risks for the financial system. Thoroval (2006) notes that the bankruptcy of companies and macroeconomic uncertainties were mainly related to credit risk management failure. It is considered that in the developing countries credit risk contains $85 \%$ of the bank risks, also seen as the main risk faced by banks. To protect against this risk, banks use a large amount of capital and create provisions for which the opportunity cost is considerable. 
According to the Credit Risk Management Regulation established by the Central Bank of Kosovo (CBK), approved on 26 April 2013, all commercial banks operating in Kosovo as part of risk management, among others, must have a credit risk management system appropriate to the nature, volume and complexity of their activities.

Commercial banks in Kosovo have established policies, manuals, various memos, procedures and strategies related to credit risk management. The objective of all these aforementioned documents for credit risk management is to harmonize effective risk management practices across the bank within a common framework that can be clearly understood and applied by all bank employees.

Among other things, the credit risk policy of commercial banks aims at providing bank management with a clear picture of their exposures. According to the $\mathrm{CBK}$ request, Board of Directors $(\mathrm{BoD})$ is responsible for establishment of the credit risk policy. Therefore, the $\mathrm{BoD}$ and the Senior Management will be responsible for the overall organisation and oversight of credit operations.

Being an inseparable part of bank risk management in Kosovo, the importance of proper credit risk management is a crucial part of the stability and flexibility of the Kosovo banking system. In every part of this research, the importance of auditing the financial statements of potential / existing clients of banks in the Kosovo banking system will be emphasised and confirmed in order to ensure quality management of credit risk.

\section{LITERATURE REVIEW}

Achievement of the objectives of this paper, as well as the correct answer to the research questions would not have been possible without a detailed review of all theoretical aspects built albeit somewhat similar to the subject in question.

Throughout the analysis, we used the method of description, comparative methodology, statistical analysis, graphics and various tables with the aim of including all the forms that make the comprehension of all the woven knit theories easier. Contributions related to audit definition were provided by Price Waterhouse Coopers auditing companies and Deloitte professors in their guidance related to audit and security services. This audit guidance provides practical approach and understanding of audit concepts and, thus, presents a more detailed view of auditing and insurance world PWC (2013).

The more we have in theory on the audit of the financial statements, the wealthier the reasons for which this type of audit exists (Howes, 2017). In this regard, every commercial bank operating in Kosovo should have a credit risk management and assessment system. Therefore, this system should include policies, procedures, rules and structures that are appropriate to the nature, purpose and complexity of their activities. In order to have an effective credit risk management policy, it should be communicated in a timely manner, reviewed regularly and applied at all levels of the bank (Siqani \& Sekiraca, 2016). However, the application of all the above-mentioned criteria makes a credit risk management system more robust. If a banking institution, in order to achieve higher profit, decides to take higher risk, then the risk should be emphasised before it is created. 
In this way, the bank may pay particular attention to the borrower's creditworthiness review to identify the borrower's weaknesses and to focus on the weaknesses of his business but not to neglect other business aspects of debtor. In such cases, depreciation provisions should be greater and loans should be provided by some collateral more (Milenkovic et al., 2011).

If banks in their investment financing process include a client whose solvency is at a high level, the credit risk will be reduced to a lower level, and vice versa. Therefore, in a way or another, audited financial statements can improve the effectiveness of monitoring.

\section{REQUIREMENTS OF THE CENTRAL BANK OF KOSOVO RELATED TO CREDIT RISK MANAGEMENT FUNCTION}

According to Credit Risk Management Regulation established by the Central Bank of Kosovo, approved on 26 April 2013, all commercial banks operating in Kosovo as part of risk management should have a credit risk management system that is appropriate to the nature, volume and complexity of their activities. Such a risk management system in banks should include policies, procedures, rules and structures used by banks to manage credit risk. In addition, according to the general requirements of the Central Bank of Kosovo, the credit risk management system should continuously and timely evaluate the quality of loans and other assets, also including determining the adequacy of reserves for losses associated with this risk (CBK, 2013).

According to the CBK requirements, the credit risk strategy should:

i. Determine the bank readiness to grant loans based on different segments of borrowers and products, type of exposure (trading, manufacturing, consumer, real estate, etc.), economic system, geographic location, currency, expected maturity and profitability;

ii. Identify target markets and overall characteristics that the bank plans to achieve in its loan portfolio, including diversification levels and concentration tolerance;

iii. Provide the quality objectives of loans, profits and growth;

iv. Ensure continuity in the approach that needs to consider the cyclical aspects of the economy and movements that result in the composition and quality of the loan portfolio.

In addition, the credit risk management policy should be reviewed on a regular basis, at least once a year, and should include at least the following elements: mission; determination of acceptable and unacceptable types of credit exposures; limiting the total of active loans in relation to total assets, deposits or capital; the combination of the desired portfolio; distribution of the portfolio according to the maturity term of the loans; defined segmentation of the market; lending conditions: price, term of return, and advance payments / capital requirements; financial information required; the definition of a qualified loan borrower; acceptable collateral and margins; the lending authorities and the approval process; restrictions on large exposures; the limit for the official creditor associated with the tire creditor's portfolio; exposures of internal persons and interrelated tire interests; 
instructions for re-programming loans; internal reports related to credit risk management; organisation of the lending function; instructions on purchasing and selling credits with the joint participation of financial institutions (CBK, 2013).

\section{METHODOLOGY}

The methodology used during the research process is based on alternation of primary and secondary data. Primary data are provided through the survey of banks operating in Kosovo, whilst for secondary data acquisition local and international literature is consulted, as well as scientific publications published in print and electronic media. At the same time, the criteria are set according to regulatory authorities' (CBK) requirements toward banks, related to credit risk management in terms of financial statement quality and other documents that banks require from their clients.

\section{SURVEY RESULTS AND STATISTICAL ANALYSIS OF RESULTS}

This section presents the final results through the survey process. Respondents in this case are domestic and foreign commercial banks performing their activity as part of the Kosovo banking system. Since this research presents rules set by the CBK main regulator and internal regulations of banks, data are presented through averages as the central indicator related to the Kosovo banking system.

The presentation of audited financial statements is an important condition because the most significant part of assets in the Kosovo banking system consists of loans and advances to customers, an exposure that requires qualitative documentation in order for these loans to flow smoothly as per their amortization plans until their maturities.

Data presented in the graphs below are statistics published in the last quarter of 2018 .

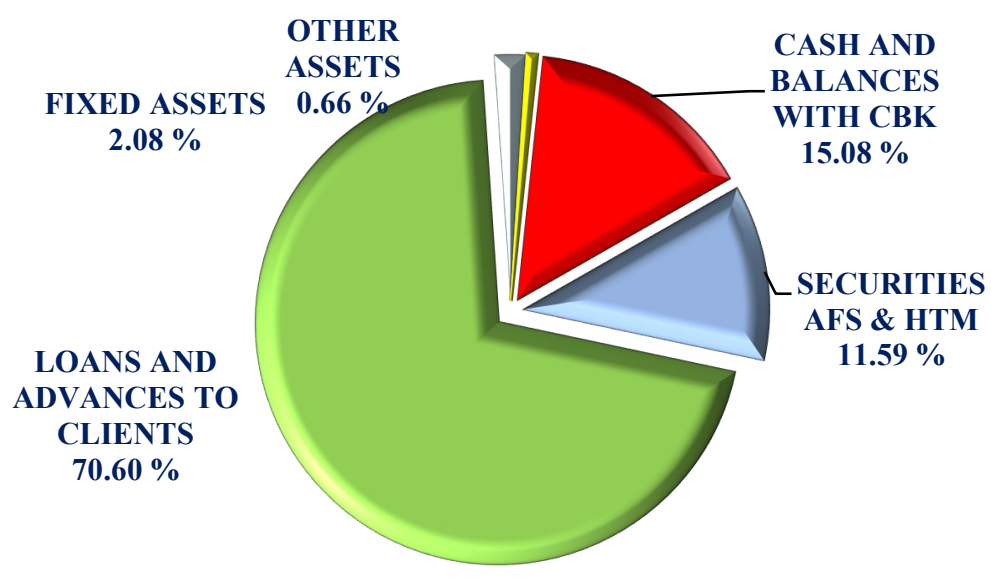

Fig. 1. Asset structure of Kosovo banking system (developed by the authors based on the CBK, 2018). 
From the Fig. 1 we can see that lending activities of commercial banks have the largest share in the structure of assets of the banking system (green color). Bank lending activity continued its upward trend characterised by the highest growth rate of $10 \%$ in the last six years. This significant increase in lending, especially in recent years, according to the CBK publications on financial stability, reflects the improved banking supply in the presence of higher credit demand. At the same time, according to the analysis based on the last quarter of 2018, compared to the third quarter, the banking system had a $3.11 \%$ growth on the credit portfolio side (Q3 2546533 EUR) and a $4.27 \%$ decrease on the loss provision side. In addition, a decrease was registered in non-performing loans by $0.18 \%(\mathrm{Q} 32.55 \%)$.

\section{Data is presented in thousand EUR}

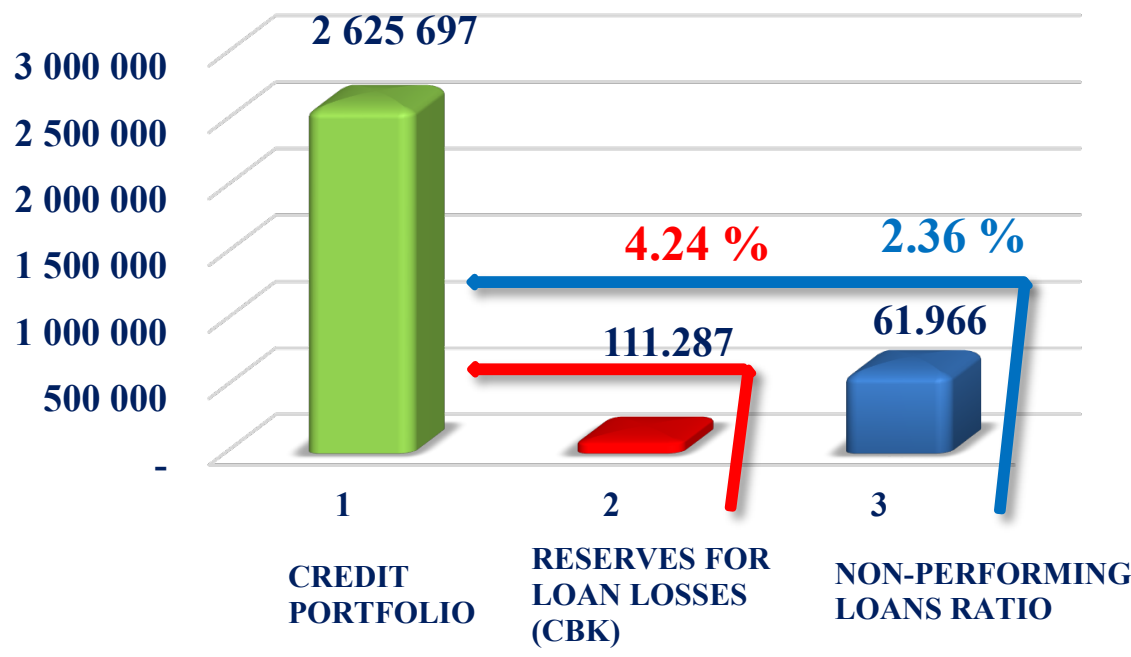

Fig. 2. Indicators of provisioning and non-performing loans in Kosovo banking sector (developed by the authors based on the CBK, 2019).

Regarding the data analysis and responses received during the survey process, all of these will be presented below, elaborated separately. First, as stated by the respondent parties, all units responsible for managing credit risk in commercial banks have in their regulatory composition: Credit Risk Management Policy and Manual, which, as required by the CBK, should be revised at least once a year.

At the same time, integral parts of the documentation of these units are: Procedures, Memorandums related to credit risk management, Strategy, and other additional documents depending on the internal strategy of these banks.

The requirement for auditing financial statements, in addition to the provision in the CBK, for credit exposures of over EUR 500000 is stated in the Manual of Credit Risk Management Department in Commercial Banks. Concerning the audit part of the financial statements, according to the answers to the questionnaire, the conclusions are presented in the figure below. 


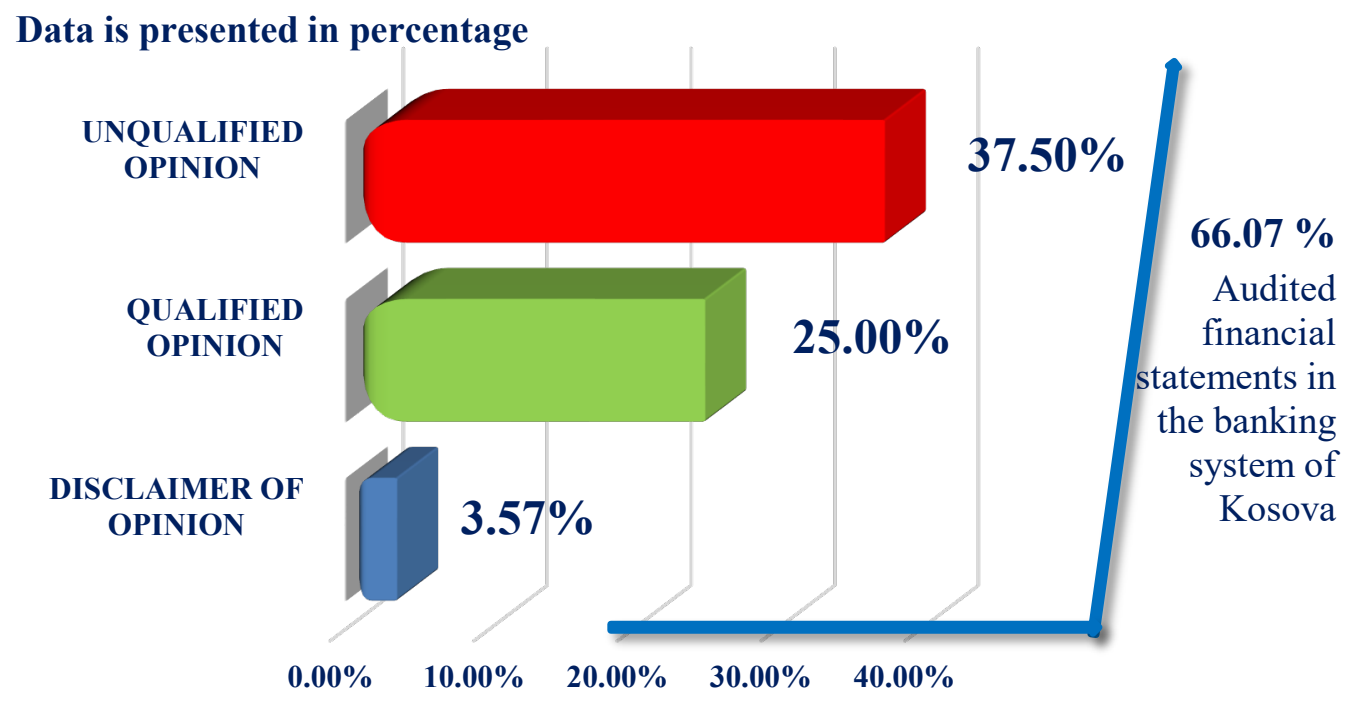

Fig. 3. Audited financial statements in the banking system of Kosovo (calculations made by the authors).

Regarding the question "Why do banks most often require financial statements audited by their clients?", commercial banks that were part of the questionnaire related to the subject matter answered as follows: for clients who have large amounts of credit exposure and occupy a high percentage in the credit portfolio of these banks, the audited financial statements are always required. Whereas for new clients, banks mainly focus on the declarations of these clients in the Tax Administration of Kosovo, but if these clients have large credit exposure requirements, then banks may also require the audited financial statements. At the same time, commercial banks have stated that they may require audited financial statements for those clients belonging to industries and branches of activity, where banks have little experience and have a low portfolio amount.

In order to validate the impact of financial statement audit on credit risk assessment in the banking system, we have formulated hypotheses regarding the key indicators of credit risk management and assessment in commercial banks.

Hypothesis 1: There is a correlation between auditing financial statements and making fair lending decisions.

We have formulated the first hypothesis under the assumption that auditing financial statements as the most credible form of information collection will help the banking system make sound decisions regarding credit portfolio management, which will indirectly affect reducing the credit risk faced by commercial banks in the Kosovo banking system. By reviewing the banking practice in the Kosovo banking system, we have found that the most appropriate way to understand whether banks' decisions regarding the fair financing of their clients is by analysing credit indicators (non-performing loans and loss rate provisions). The variables used for testing the first hypothesis are the analysis of the performance of the Kosovo banking system for the period of 2014-2018, the value of the banking 
system credit portfolio, the value of credit exposures in excess of EUR 500 000, the rate of non-performing loans and the rate of provision for losses for the respective years. To confirm the first hypothesis regarding the relevance of the audit of financial statements and fair lending decisions, we have used correlation through the statistics above.

Table 1. Correlation

\begin{tabular}{|c|c|c|c|}
\hline \multicolumn{2}{|l|}{ Model } & $\begin{array}{c}\text { Non-performing loans } \\
(\%)\end{array}$ & $\begin{array}{c}\text { Financial statement audit } \\
(\%)\end{array}$ \\
\hline \multirow[t]{3}{*}{$\begin{array}{l}\text { Non-performing loans } \\
(\%)\end{array}$} & $\begin{array}{l}\text { Pearson } \\
\text { Correlation }\end{array}$ & 1 & $-0.963^{* * *}$ \\
\hline & Sig. (2-tailed) & & 0.001 \\
\hline & $\mathrm{N}$ & 7 & 7 \\
\hline \multirow[t]{3}{*}{$\begin{array}{l}\text { Financial Statement Audit } \\
(\%)\end{array}$} & \begin{tabular}{|l|} 
Pearson \\
Correlation \\
\end{tabular} & $-0.963^{* * *}$ & 1 \\
\hline & Sig. (2-tailed) & 0.001 & \\
\hline & $\mathrm{N}$ & 7 & 7 \\
\hline
\end{tabular}

For the sake of result clarification, we mention that the correlation can be represented by values between the intervals -1 and 1 . Based on the results presented above, which are derived from the SPSS data entry, we note that the correlation coefficient 10 is -0.963 , very close to -1 , which means that the audit of the financial statements and the rate of non-performing loans in our example have a negative relationship with each other, so with the increase of one decreases the other and vice versa. Thus, we have sufficient evidence to accept the first hypothesis, $\mathrm{H}_{0}$ : There is a correlation between financial statement audit and fair lending decisions.

Hypothesis 2: Reducing the uncertainty of information contained in financial statements has a significant impact on interest rates applied by banks.

The second hypothesis is built on the assumption that the audit of financial statements has an indirect impact on lowering the interest rates offered by commercial banks to their clients that present consolidated and credible information that enhances the safety of banks along with the decisions they make as well belongs to their customers.

Table 2. Determination Coefficient

\begin{tabular}{|c|c|c|c|c|}
\hline Model & $\boldsymbol{R}$ & $\boldsymbol{R}$ Square & Adjusted $\boldsymbol{R}$ Square & Std. Error of the Estimate \\
\hline 1. & $0.963^{\mathrm{a}}$ & $\mathbf{0 . 9 2 7}$ & 0.912 & 6.225422291865515 \\
\hline
\end{tabular}

From the model summary table, the coefficient of determination explains $92.7 \%$ of the variation in the outcome of customer interest rates with credit exposures greater than EUR 500000 which have provided audited financial statements. 
Table 3. Coefficients ${ }^{\mathrm{a}}(p$-value)

\begin{tabular}{|c|c|c|c|c|c|c|}
\hline \multirow{2}{*}{\multicolumn{2}{|c|}{ Model }} & \multicolumn{2}{|c|}{$\begin{array}{l}\text { Unstandardised } \\
\text { Coefficients }\end{array}$} & $\begin{array}{l}\text { Standardised } \\
\text { Coefficients }\end{array}$ & \multirow[t]{2}{*}{$t$} & \multirow[t]{2}{*}{ Sig. } \\
\hline & & $B$ & Std. Error & Beta & & \\
\hline \multirow[t]{2}{*}{1} & (Constant) & 82.435 & 4.146 & & 19.883 & 0.000 \\
\hline & $\frac{\left(b_{1}\right) \text { Financial }}{\text { Statements Audit }(\%)}$ & -0.859 & 0.108 & -0.963 & -7.964 & 0.001 \\
\hline
\end{tabular}

Since the $p$ value for the coefficient $b_{1}$ (PFA) is 0.001 and is significantly lower than 0.05 , we have sufficient evidence to accept our hypothesis. Therefore, we can conclude that the financial statement audit has a significant impact on determining the interest rate for clients who provided these financial statements.

\section{CONCLUSION}

Based on published statistics, the overall result of the study shows that commercial banks in Kosovo and the financial system, in general, have little sustainability on consolidated and audited financial information, whereas credit risk management is really focused on other methods before and after the lending activity.

In their internal documents that assist the credit risk management process, commercial banks have stated only the provision that should be allocated to the CBK for credit exposures of amounts over EUR 500000 that are not supported by audited financial statements. This criterion is set in "Regulation on Credit Risk Management" published by the CBK. Otherwise, no other requirement related to financial statements audit is established in any bank internal document.

By the end of 2018, statistics show that around $69.42 \%$ of the assets of the banking system consist of loans and advances for customers, i.e., a credit portfolio of EUR 2.46 billion, where $16 \%$ of this portfolio is occupied by credit exposures worth more than EUR 500 000. As commercial banks have stated, $66.07 \%$ of these credit exposures are based on audited financial statements. This indicates that commercial banks are more focused on setting criteria regarding financial information in those exposures, which occupy a significant percentage in the loan portfolio in order to reduce credit risk and at the same time to lower the provision amount.

Based on the analysis, we can see that only $2.19 \%$ of the clients with audited financial statements are classified as overdue loans. This implies that the essential part of these clients are classified as standard clients with loan arrears not more than 30 days. This high concentration is related to credible and consolidated information as well as "close monitoring".

In the relevant years, we have found that there is a significant negative correlation between the audit of financial statements and the NPL ratio. We have come to this conclusion by analysing the flow of activity in the Kosovo banking 
system for the period of 2014-2018, the value of the banking system credit portfolio, the value of credit exposures in excess of EUR 500 000, the NPL ratio and provisioning for loss-related loans. In this regard, we have sufficient evidence to conclude that there is a correlation between financial statement audit and fair lending decisions.

The coefficient of determination derived from the input of the respective variables in SPSS explains $92.7 \%$ of the variation as a result of interest rates for clients with credit exposures greater than EUR 500000 supported by audited financial statements. At the same time, the $p$ value for the coefficient $b_{1}$ (audited financial statements) is 0.001 , which is less than 0.05 . Consequently, we have enough evidence to accept our second hypothesis. Thus, the audit of financial statements has a significant impact on determining the interest rate of clients who provided these financial statements.

\section{RECOMMENDATIONS}

The correlation coefficient shows that there is a strong negative relationship between the NPL ratio and the audit of financial statements. Therefore, it is recommended to increase the percentage of audited financial statements in order to decrease the NPL ratio. At the same time, this will be a key indicator that will positively affect the performance of credit risk management.

Considering the other factors as insignificant, the coefficient of determination demonstrates that a significant percentage of the interest rates on credit exposures above EUR 500000 has been determined by considering audited financial statements as a relevant factor. Therefore, we recommend that, among other elements, the audit of financial statements should be a key part of the checklists that determine the interest rates for various clients who provide these statements.

The coefficient of determination also shows that credit exposures over EUR 500000 are of great importance in the quality of loan portfolio as well as in NPL ratio. Therefore, it is recommended that commercial banks cooperate with their clients by financing part of the audit costs of client financial statements.

According to the CBK reporting rules, bank provisions are reduced in the case of increased credit performance. Banks allocate significant amounts to the CBK as provision for their losses. In this regard, these funds would have been allocated for new exposures if existing exposures were properly managed. In such a situation, it is recommended that banks should aim at keeping the majority of their loan portfolio as a standard. This aim would be achieved with strict credit risk management policies, as it is the main risk that the banking system of Kosovo faces. 


\section{REFERENCES}

CBK. (2013). Regulation on Credit Risk Management - Neni 3. Prishtina: Official Gazette of the Republic of Kosovo.

CBK. (2019). CBK Report. Vlerësimi Tremujor i Sistemit Financiar No. 29, Tremujori IV/2019. https://bqk-kos.org/repository/docs/2015/BQK_TM4_2019\%20Sistemi\%20Financiar..pdf

Central Bank of Kosovo. (2013). Regulation on Credit Risk Management - Article 3. Prishtina: The official newspaper of Republic of Kosovo.

Howes, C. (2017). Reasons for financial statement audit. Retrieved from

https://www.academia.edu/35492018/REASONS_FOR_AUDITING_FINANCIAL_STATEMEN TS

Milenkovic, N., Pjanic, M. \& Ostojic, S. (2011). Credit risk analysis based on financial statements as the key influencing factor on investor risk. International Symposium Engineering Management and Competitiveness. Zrenjanin, Serbia.

PWC. (2013). Understanding a financial statement audit. Retrieved from https://www.pwc.com/gx/en/audit-services/publications/assets/pwc-understanding-financialstatement-audit.pdf

Siqani, S. H., \& Sekiraca, E. (2016). The Impact of the Internal Audit in Reducing Credit Risk in Commercial Banks in Kosovo. European Scientific Journal, 12(4). https://doi.org/10.19044/esj.2016.v12n4p268

Thoraval, P. Y. (2006). Stress-Testing on Credit Risk: Macroprudential Supervision: Challenges for Financial Supervisors. Secrétariat général de la Commission bancaire.

\section{AUTHORS' SHORT BIOGRAPHIES}

Albina Kalimashi, MSc, is a professional banker that actually works as the key staff of Treasury Sector at a national bank in Kosovo, named "Banka per Biznes". At the same time, she is part of the Public University of Prishtina, Faculty of Mathematical \& Natural Sciences, where she works as an Assistant Lecturer in charge of delivering study courses of the Economics Department. Albina finished Bachelor and Master studies with distinction at the Faculty of Economics, Department of Banking, Finance and Accounting at the University of Prishtina. She is certified in different banking training fields, such as treasury, financial risk and ToT, risk management, most of them attended by ATTF, GARP, and EBRD.

E-mail: albina.kalimashi@uni-pr.edu

Yllka Ahmeti, PhD, finished Bachelor and Master studies at the Faculty of Economics, Department of Banking, Finance and Accounting at the University of Prishtina. She is a $\mathrm{PhD}$ candidate at the University of Tetova, North Macedonia. She has been working as a Banking Supervisor at the Central Bank of Kosovo for 7 years.

E-mail: ahmeti.yllka@gmail.com

Ardi Ahmeti, MSc, is an entrepreneur and independent researcher. He has finished both Bachelor and Master studies with distinction at the Faculty of Economics, Department of Banking, Finance and Accounting at the University of Prishtina. Currently, he works as an independent researcher and owns a private consulting firm based in Prishtina with the main focus on issues pertaining to accounting and finance.

E-mail: ardisahmeti@gmail.com 